\title{
The Effects of Drying Method on the Wood Permeability, Wettability, Treatability, and Gluability of Southern Pine from Australia
}

\author{
William Leggate, ${ }^{\mathrm{a}, \mathrm{b}, *}$ Chandan Kumar, ${ }^{\mathrm{b}}$ Robert L. McGavin, ${ }^{\text {,cc }}$ Adam Faircloth, ${ }^{\mathrm{b}}$ and \\ Mark Knackstedt ${ }^{\mathrm{a}}$
}

\begin{abstract}
Drying has a major impact on the viability of sawn timber production, particularly through its influence on productivity, energy usage, and product quality. Traditionally, plantation-grown southern pine structural grade timber from Australia has been dried using high temperature $(\geq 180$ ${ }^{\circ} \mathrm{C}$ ) conventional batch kilns. However, the Australian industry is showing increasing interest in continuous drying kilns because of reported cost savings and potential improvements in product quality. This study investigated the differences between continuous drying and conventional drying schedules on the radial permeability, wettability, gluability, and treatability of southern pine timber from Queensland plantations. The high temperature drying resulted in significantly lower liquid permeability compared to low temperature drying; however, there were no significant differences between drying schedules for gas permeability. For combined wood surface and core data, there were no significant differences in liquid permeability between low temperature drying and continuous drying or between continuous drying and high temperature drying schedules. For earlywood after surface machining, continuous drying resulted in the greatest wettability (based on $K$-values), whereas for latewood after surface machining, low temperature drying produced the greatest wettability. Earlywood had greater wettability compared to latewood. Continuous drying resulted in better gluability and treatability compared to conventional drying schedules.
\end{abstract}

Keywords: Wood drying; Continuous drying; Wood wettability; Wood permeability; Wood gluability; Wood treatability; Pinus elliottii; Pinus caribaea; Southern pine

Contact information: a: Research School of Physics and Engineering, The Australian National University, Canberra, ACT 0200, Australia; b: Queensland Department of Agriculture and Fisheries, Horticulture and Forestry Science, Salisbury Research Facility, 50 Evans Rd, Salisbury, Qld 4107, Australia; c: School of Civil Engineering, The University of Queensland, St Lucia, Qld 4072, Australia

*Corresponding author: william.leggate@daf.qld.gov.au

\section{INTRODUCTION}

Drying is a critical component in sawn timber production and has a major influence on the profitability of sawmills. Wood drying is essential to 1) provide dimensional stability; 2) improve strength; 3 ) reduce the moisture content to an acceptable level for wood preservation, gluing, finishing, and other manufacturing processes; 4) improve the durability and resistance to biological degradation; and 5) reduce the weight and minimise costs in handling and transport. For the sawn timber production process, converting logs to finished dried wood components, drying can consume up to $70 \%$ of the energy and $90 \%$ of the time, depending upon species and product type (Kumar and Redman 2019). 
Therefore, drying is often considered the bottleneck of the production process (Redman 2017; Kumar and Redman 2019).

In Australia, for more than 25 years, the most common drying method for sawn timber of southern pine (Pinus elliottii (PEE), Pinus caribaea $(\mathrm{PCH})$, and $\mathrm{PEE} \times \mathrm{PCH}$ : the hybrid between these two species), and other exotic (to Australia) pines such as radiata pine (Pinus radiata) has been high temperature conventional batch kiln drying, where temperatures can exceed $180{ }^{\circ} \mathrm{C}$, and drying times can be less than $12 \mathrm{~h}$. However, internationally, the relatively new continuous drying (CD) kiln technology for kiln drying structural softwood sawn timber is increasingly replacing conventional kilns (Oliveira and Lazarescu 2018; Kumar and Redman 2019; Windsor Engineering Group 2020). The CD method results in major reductions in energy usage and drying costs. Timber stacks dried in typical CD kilns pass through the kiln in opposite directions on two tracks, so that heat coming off the dried, exiting timber preheats the timber packs entering the drying process, and moisture coming off the undried timber conditions the dry timber. This energy-efficient process happens at both ends. Significant thermal energy efficiencies of approximately $30 \%$ can be achieved with CD kilns, with several other reported benefits for product quality (Friday Offcuts 2011; Kumar and Redman 2019). The Australian softwood processing industry is showing interest in this technology due to anticipated savings in energy and production costs. However, the effects of this drying method on dried wood quality and key wood properties such as permeability, wettability, gluability, and treatability are unknown for plantation-grown southern pine timber in Australia. The wood quality and characteristics of southern pine grown in plantations in Australia are expected to vary from those of southern pine in the USA due to differences in genotypes, silviculture, climate, and other growing conditions. The hybrid pine $(\mathrm{PEE} \times \mathrm{PCH})$ now dominates exotic softwood plantations and log supply in Queensland, Australia, with approximately 94,100 ha planted and an annual log production soon to exceed 1 million cubic meters per year (Leggate et al. 2019).

Permeability is a measure of the ease with which liquids and gases flow through a porous substance under the influence of a pressure gradient (Comstock 1968; Tesoro 1973; Booker 1990; Milota et al. 1995; Hansmann et al. 2002; Lee et al. 2008; Leggate et al. 2019). The permeability of wood influences many of its important processing and utilization properties, including gluing, drying, preservation, wood modification systems, pulping, finishing, and even durability (Fogg 1968; Tesoro 1973; Hansmann et al. 2002; Zimmer et al. 2014; Leggate et al. 2019).

Wood permeability is significantly influenced by drying conditions (Bamber 1972; Booker 1990; Booker and Evans 1994; Hansmann et al. 2002; Lee et al. 2008; Ahmed et al. 2012, 2013; Tarmian et al. 2020). Many studies have shown that higher temperature drying tends to increase permeability because of effects on the wood microstructure such as the collapse of thin-walled cells resulting in interstitial spaces; rupturing in the pit torus, pit borders, and cell walls; and creation of micro-checks caused by the high temperature drying process that improves liquid penetration (Tiemann 1910; Weiss 1912; Booker and Evans 1994; Zhang and Cai 2008; Lande et al. 2010). Drying conditions also influence the movement and modification of natural resin in the wood, which can then influence permeability (Booker and Evans 1994; Winandy et al. 2001). However, no studies have reported the effects of continuous drying on the permeability of Queensland-grown southern pine. 
Wettability refers to an adherend's ability to attract a liquid, such as an adhesive (Hovanec 2015). Adequate wetting of the surfaces of wood adherends is necessary to achieve a strong adhesive bond (Wellons 1980; River et al. 1991; Hovanec 2015). A typical method used to assess wood wettability is liquid droplet contact angle measurement (Leggate et al. 2020). Wood surfaces which have been exposed to a high temperature condition can experience surface inactivation or reduced wettability, and higher temperature drying reduces wood wettability (Sernek 2002; Šernek et al. 2004; Navickas et al. 2015).

The gluing of wood is a mainstream manufacturing process, with large volumes of southern pine timber being glued to produce engineered wood products such as glued laminated timber (glulam). Understanding the impacts of different drying conditions on timber gluability is important for optimising the manufacture of glued wood products and avoiding bond performance problems and product failures.

Wood treatment with chemicals such as preservatives, fire retardants, and water repellents is used to improve the performance of wood. In Australia, the majority of the southern pine sawn timber production is treated with insecticides and/or fungicides to prevent degradation in service. Treatability measures the extent to which a porous material such as wood can be impregnated with liquids such as wood preservatives (Tarmian et al. 2020). The treatability of wood is usually measured by the amount of uptake of preservative solution, active ingredient penetration, and retention. Wood treatability is usually closely related to wood permeability, so factors that affect wood permeability can be expected to similarly affect wood treatability (Siau 1984). However, no significant link was found between the method of drying and treatability in studies by Lebow et al. (2006) and Jewell et al. (1990) on southern pine species from the USA, although a non-significant trend was found by Jewell et al. (1990), indicating that higher temperature schedules may increase preservative penetration.

Given the strong interest by the Australian softwood industry to investigate continuous drying methods, attracted by the promoted benefits of potential energy usage reductions and cost savings, this study sought to overcome the scarcity of information on the effects of this drying method on key wood performance criteria. This study directly compared the effects of continuous kiln drying versus conventional drying methods on the permeability, wettability, gluability, and treatability of southern pine timber from Queensland, Australia.

\section{EXPERIMENTAL}

\section{Sample Preparation from Unseasoned Timber}

Fifty-six boards of backsawn, unseasoned (average moisture content (MC) of 84\%) southern pine timber with nominal dimensions of $100 \mathrm{~mm} \times 38 \mathrm{~mm} \times 6000 \mathrm{~mm}$ (width $(\mathrm{W}) \times$ thickness $(\mathrm{T}) \times$ length $(\mathrm{L}))$ were obtained from a major commercial sawmill in Queensland, Australia. Samples of $100 \mathrm{~mm} \times 38 \mathrm{~mm} \times 900 \mathrm{~mm}(\mathrm{~W} \times \mathrm{T} \times \mathrm{L})$ (nominal dimensions) were cut from each board and then randomly allocated to three different drying regimes (Fig. 1). The 900-mm lengths were immediately end-sealed with a polyurethane sealant (Sikaflex, Sika AG, Baar, Switzerland), weighed (for MC monitoring during drying), wrapped in plastic, and then stored in a cold room at $4{ }^{\circ} \mathrm{C}$ until the drying experiments commenced. 


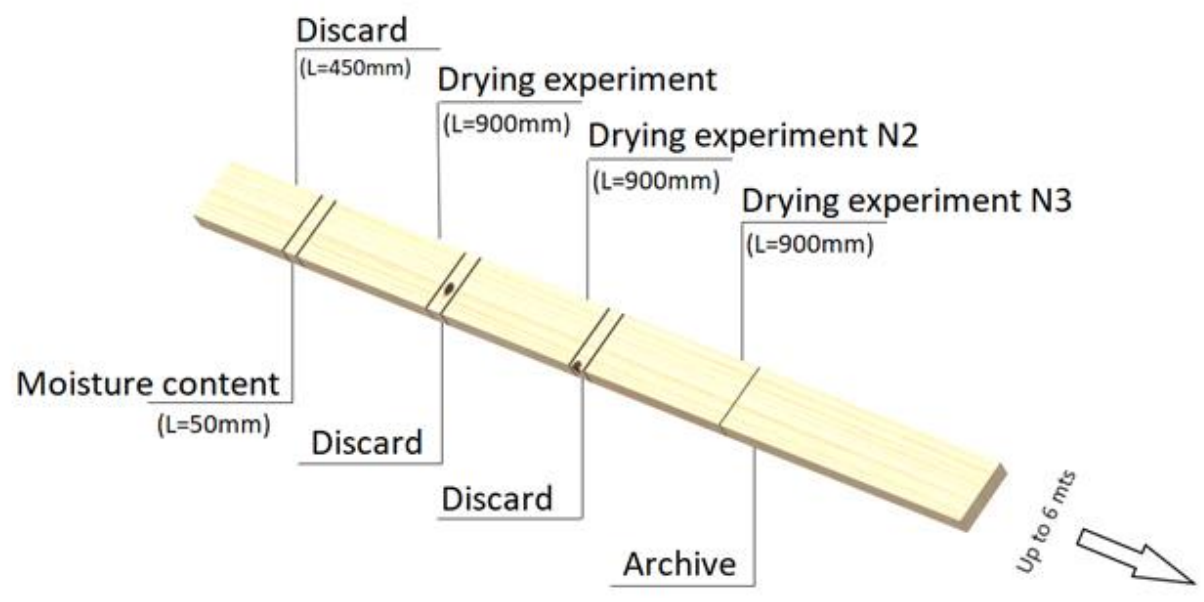

Fig. 1. Sample cutting from green boards for drying experiments

\section{Drying}

Table 1 provides details on the three different drying regimes adopted. The low temperature drying was performed initially in a constant environment chamber set at $20{ }^{\circ} \mathrm{C}$ and $45 \%$ relative humidity ( $\mathrm{RH}$ ) (approximately $8 \%$ equilibrium moisture content (EMC)) for $384 \mathrm{~h}(16 \mathrm{~d})$. The boards were then dried in an experimental kiln at $40{ }^{\circ} \mathrm{C}$ dry bulb temperature (DB) and 48\% RH (approximately 8\% EMC) with an air velocity of $3 \mathrm{~m} / \mathrm{s}$ for $52 \mathrm{~h}$. The total drying time of the low temperature dried boards was $436 \mathrm{~h}$ (approximately $18 \mathrm{~d}$ ). High temperature drying was undertaken in an experimental kiln with a schedule representative of typical high temperature drying schedules used for drying softwood structural-grade sawn timber in Australia. Set points ranged from $25{ }^{\circ} \mathrm{C}$ to $180{ }^{\circ} \mathrm{C} \mathrm{DB}$, $7.3 \%$ to $82 \% \mathrm{RH}, 0 \%$ to $12 \% \mathrm{EMC}$, and $3 \mathrm{~m} / \mathrm{s}$ to $7 \mathrm{~m} / \mathrm{s}$ air flow depending on the stage of the drying schedule. The total drying time was 477 min $(8 \mathrm{~h})$. Continuous drying was undertaken in an experimental kiln with a schedule representative of typical drying conditions targeted with continuous drying kilns for structural-grade softwood timber. Set points ranged from $25{ }^{\circ} \mathrm{C}$ to $115{ }^{\circ} \mathrm{C} \mathrm{DB}, 34 \%$ to $100 \% \mathrm{RH}, 2.3 \%$ to $23 \% \mathrm{EMC}$, and $3 \mathrm{~m} / \mathrm{s}$ to $5.5 \mathrm{~m} / \mathrm{s}$ air flow depending on the stage of the drying schedule. The total drying time was $36 \mathrm{~h}$.

Table 1. Maximum Temperature and Sample Number for Each Drying Group

\begin{tabular}{|c|c|c|}
\hline Drying Group & $\begin{array}{c}\text { Maximum Drying Temperature } \\
\left({ }^{\circ} \mathrm{C}\right)\end{array}$ & Number of Samples \\
\hline $\begin{array}{c}\text { Low Temperature Drying } \\
\text { Schedule }\end{array}$ & 40 & 35 \\
\hline Continuous Drying Schedule & 115 & 29 \\
\hline $\begin{array}{c}\text { High Temperature Drying } \\
\text { Schedule }\end{array}$ & 180 & 33 \\
\hline
\end{tabular}


Moisture content was monitored throughout the drying process using load cells and board weight. After kiln drying, all boards were conditioned to $12 \% \mathrm{MC}$ in a constant environment chamber set at $20{ }^{\circ} \mathrm{C}$ and $65 \% \mathrm{RH}$ (12\% EMC) until board weight stabilised.

\section{Sample Preparation from Dried Timber}

After conditioning, a 450-mm-length piece was removed from each 900-mm dried board. Samples were then obtained from the surface and core (mid-board thickness) of the 450-mm piece for the determination of permeability, gluability, and treatability as shown in Fig. 2. An additional sample from the full cross section was also obtained for wettability tests (Fig. 2).

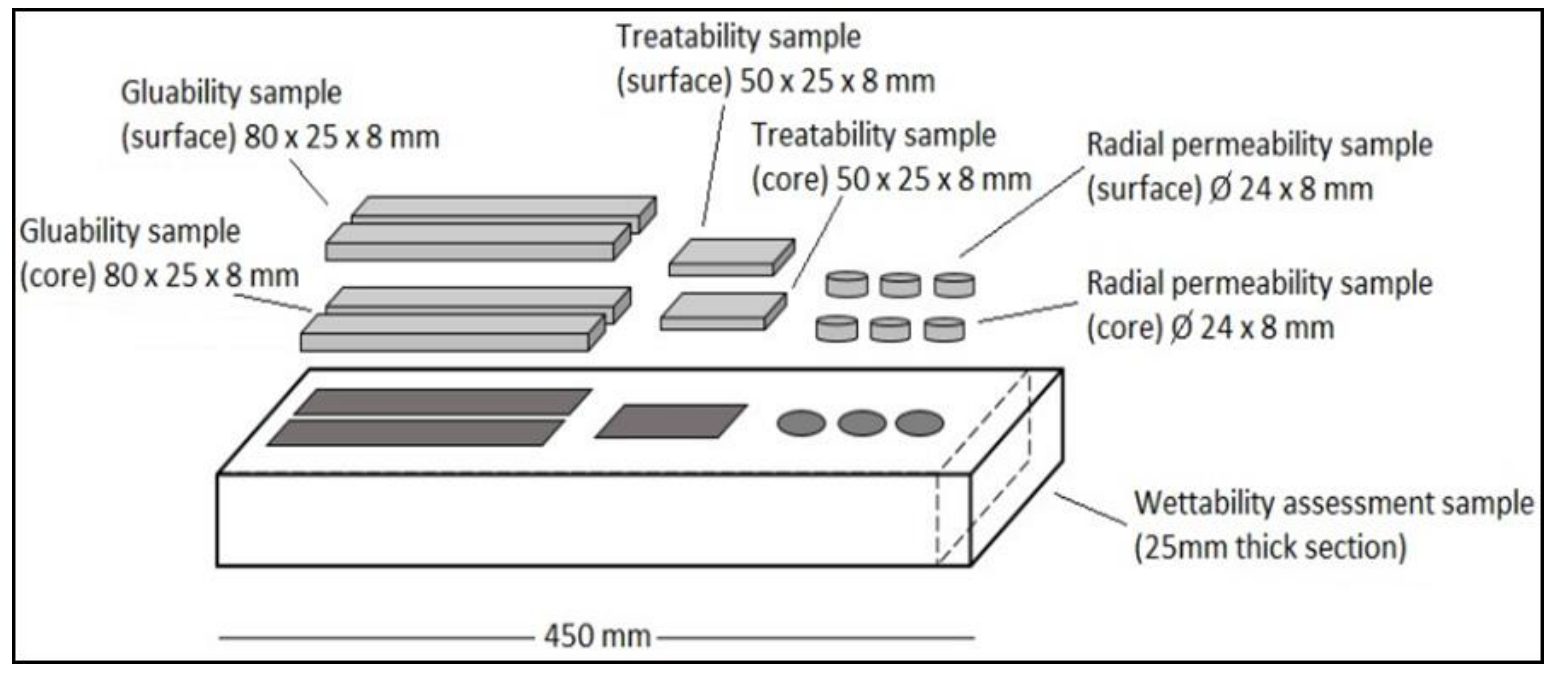

Fig. 2. Sample cutting from dried boards for permeability, treatability, gluability, and wettability tests

\section{Permeability}

The methodology adopted for the permeability tests was similar to that adopted by Leggate et al. (2020). Samples for the permeability tests were $24 \mathrm{~mm}$ in diameter and 8 $\mathrm{mm}$ in thickness (flow direction). The edge of each sample was coated with epoxy resin on its lateral surface to direct gas and liquid movement in the radial direction to measure only the wood radial permeability.

Radial permeability measurements were undertaken using a POROLUX 1000 porometer (IB-FT GmbH, Berlin, Germany). Both gas and liquid permeability were measured, with gas permeability tests undertaken before liquid permeability tests. For gas permeability, samples were subjected to pressurized, atmospheric air until the pressure reached the target pressure of 4000 millibars. For liquid permeability, samples were subjected to pressurized water (non-distilled) with a constant pressure of 4000 millibars for 5 min. Permeability was calculated in accordance with Darcy’s law (Eq. 1),

$$
Q=K \cdot \frac{A}{L} \cdot \frac{1}{\eta} \Delta P
$$

in which $Q, K, A, L, \eta$, and $\Delta P$ are the liquid or air volume flow rate $\left(\mathrm{m}^{3} / \mathrm{s}\right)$, the permeability of the wood $\left(\mathrm{m}^{2}\right)$, area perpendicular to the liquid flow $\left(\mathrm{m}^{2}\right)$, the sample length in the direction of flow $(\mathrm{m})$, the dynamic viscosity of the liquid or air $(\mathrm{Pa} \cdot \mathrm{s})$, and the pressure decrease $(\mathrm{Pa})$, respectively (Kucerová 2012). 


\section{Wettability}

The wettabilities of the samples were determined using the sessile drop method, by measuring the contact angle of a drop of pure water on the timber surface (Fig. 3) (Burch 2015; Leggate et al. 2020). Testing followed the methodology developed by Leggate et al. (2020). The contact angle is the angle that the liquid forms when in contact with a solid, as shown in Fig. 3 (Burch 2015). Because the tendency of a liquid to spread increases as contact angle decreases, the determination of contact angles is a useful inverse measure of wettability (Zisman 1964; Leggate et al. 2020). Contact angles were measured before and immediately after surface machining to a $1.5-\mathrm{mm}$ depth. The surface machining was undertaken using a Ledinek Rotoles 400 D-S (Hoče, Slovenia) face miller with a feed rate of $45 \mathrm{~m} / \mathrm{min}$ and a cutter speed of $2100 \mathrm{rpm}(57 \mathrm{~m} / \mathrm{s})$. Contact angles were measured on both earlywood and latewood for each sample.

An electronic pipette (Labco electronic pipettor, Labco Limited, Lampeter, UK) was mounted on a stand, so that the default position of the pipette tip was approximately $20 \mathrm{~mm}$ from the sample surface. The pipette could be moved vertically towards the sample surface to place a water droplet onto the sample surface but automatically retracted once manual control was released. A video camera (Samsung Galaxy A20, Samsung, Seoul, South Korea) was positioned approximately $10 \mathrm{~mm}$ in front of the sample and level with the timber surface. The camera was used to record the process of the droplet being applied and spreading on the sample surface. A clip-on macro lens (Apexel, APL-24XMH, Shenzhen Apexel Technology Co., Ltd, Shenzhen, Guangdong, China) was attached to the camera to provide adequate magnification of the droplet. The macro lens and camera combined provided a total of approximately $50 \times$ magnification $(21 \times$ from the macro lens and approximately $2.5 \times$ from the camera). The camera was securely mounted to prevent movement and vibration. A droplet of $1 \mu \mathrm{L}$ of water (HPLC grade) was dispensed from the pipette per test. The pipette was manually repositioned towards the sample surface to aid dispensing and then immediately retracted once the droplet moved onto the sample surface. The process of the droplet dispensing and at least $10 \mathrm{~s}$ following were recorded by video.

For each sample, screenshots of the video were saved as images at specific times. The first image was taken once the pipette had applied the droplet on the surface (Fig. 4a). Then, one image was taken per second for $10 \mathrm{~s}$, providing a total of 11 contact angle images. These images were processed by the open-source image-processing software ImageJ (IJ 1.46r) (U.S. National Institutes of Health, Bethesda, MD, USA) (Schneider et al. 2012) with the contact angle plugin (Lamour et al. 2010) (Fig. 4b). For each image measurement with the software, two points were manually selected at the intersection of solid-liquid-air interfaces (marked by an arrow in Fig. 4a) to define the baseline, and four points were selected along the drop profile. The software contact angle plugin then fitted the points with the sphere approximation or ellipse approximation and calculated the contact angle.

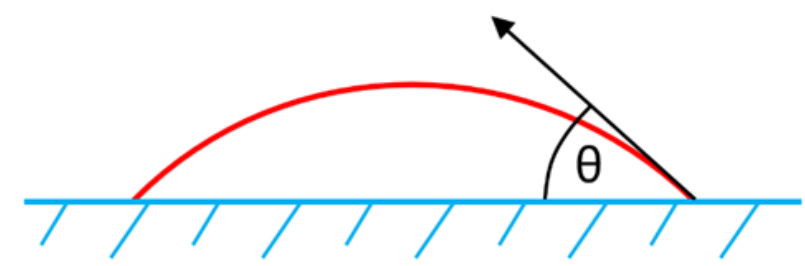

Fig. 3. Contact angle ( $\theta$ ) for a liquid droplet on a solid surface (Burch 2015; Leggate et al. 2020) 


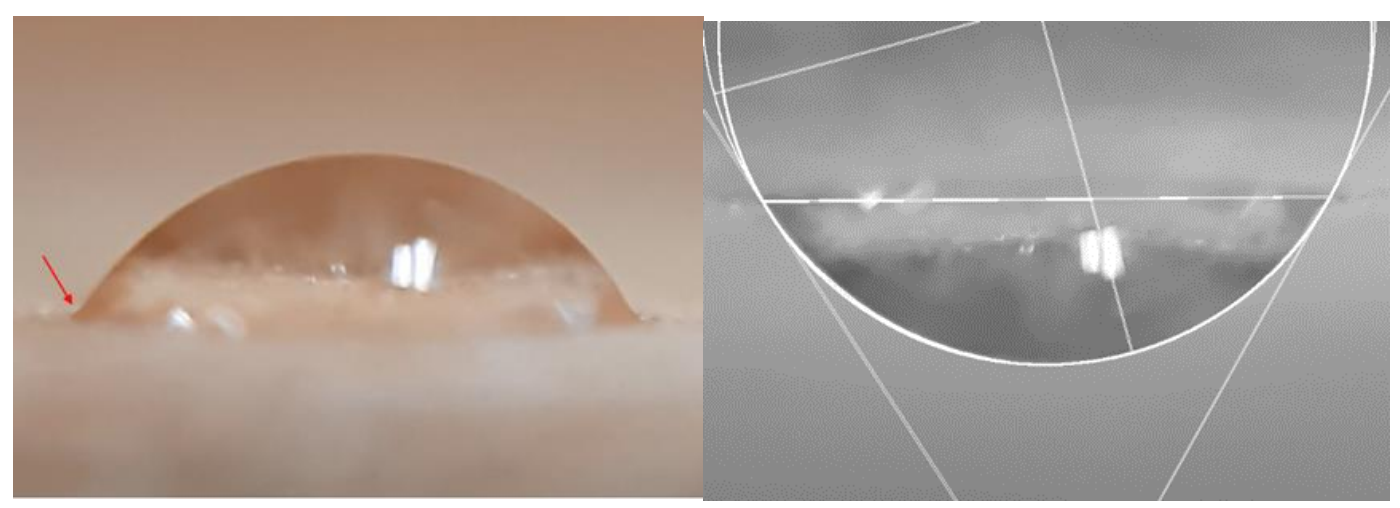

(a)

(b)

Fig. 4. Water droplet in contact with timber surface: (a) a drop of water on timber surface and (b) the same drop processed with the software (the image is inverted as part of the processing) (Leggate et al. 2020).

The change in contact angle over time was assessed using the wettability model developed by Shi and Gardner (2001) for wood. This wettability model has been adopted by many researchers for assessing the wettabilities of various wood surfaces (Qin et al. 2014; Burch 2015; Wang et al. 2015; Leggate et al. 2020). The model was developed to quantify the change in contact angle over time. The wetting model is shown in Eq. 2,

$$
\theta=\frac{\theta_{\mathrm{i}} \theta_{\mathrm{e}}}{\theta_{\mathrm{i}}+\left(\theta_{\mathrm{e}}-\theta_{\mathrm{i}}\right) \exp \left[K\left(\frac{\theta_{\mathrm{e}}}{\theta_{\mathrm{e}}-\theta_{\mathrm{i}}}\right) t\right]}
$$

where $\theta_{\mathrm{i}}$ is the initial contact angle at time $0 \mathrm{~s}, \theta_{\mathrm{e}}$ is the equilibrium contact angle (for the data of this study, at the test time of $10 \mathrm{~s}$ ), $t$ is time (s), and $K$ is the constant intrinsic relative contact angle decrease rate $(1 / \mathrm{s})$. The $K$-value represents the rate at which a liquid spreads and penetrates across or into the wood substrate (Shi and Gardner 2001; Burch 2015; Leggate et al. 2020). A high $K$-value represents a liquid that quickly spreads and/or penetrates into the wood surface, while a low $K$-value represents a liquid that slowly spreads and/or slowly penetrates into the wood surface. A $K$-value of zero represents no change between initial and equilibrium contact angles (Burch 2015). The nonlinear least squares method was used to estimate the $K$-value of the nonlinear model using RStudio (Studio Version 1.1.453, RStudio, Boston, MA, USA) (Baty et al. 2015). The contact angle values at the times $0 \mathrm{~s}$ and $10 \mathrm{~s}$ were assigned as the initial $\left(\theta_{\mathrm{i}}\right)$ and equilibrium $\left(\theta_{\mathrm{e}}\right)$ contact angles, respectively. For a typical exponential decay of a contact angle $v$ s. time curve, the $K$ values were approximately between 0.1 to 1.0 (Burch 2015); therefore the initial value of $K$ was assigned to 0.3 .

\section{Gluability}

Lap shear specimens were prepared from the surfaces and cores of samples from each drying group (Fig. 2) following the principles of the European Standard BS EN 205 (2016). The lap shear specimens were prepared with samples that had been machined using the face miller with a feed speed of $45 \mathrm{~m} / \mathrm{min}$ and a cutter speed of $3000 \mathrm{rpm}(82 \mathrm{~m} / \mathrm{s})$. The depth of face milling was $1.5 \mathrm{~mm}$. The lap shear sample dimensions are shown in Fig. 5 . The adhesive-bonded overlap in the lap shear samples was $10 \mathrm{~mm}$ (Fig. 5). 
The application of adhesive commenced within 20 min of surface machining. A one-component moisture-curing polyurethane (1C-PUR) adhesive (Jowat Jowapur 681.40, Jowat SE, Detmold, Germany) was used. This glue type is representative of a typical glue used commercially in softwood structural glulam production. In accordance with the technical data sheet for this adhesive, the lap shears had 1C-PUR applied at a spread rate of $250 \mathrm{~g} / \mathrm{m}^{2}$ (gsm). Open assembly time was $10 \mathrm{~s}$, and closed assembly time was $5 \mathrm{~min}$ to $20 \mathrm{~min}$.

The lap shear samples were then pressed at $0.8 \mathrm{MPa}$ for a minimum of $100 \mathrm{~min}$. After pressing, the lap shear samples were then conditioned in a constant environment chamber set at $20{ }^{\circ} \mathrm{C}$ and $65 \% \mathrm{RH}(12 \%$ EMC) for a minimum of $7 \mathrm{~d}$ before tensile strength testing.

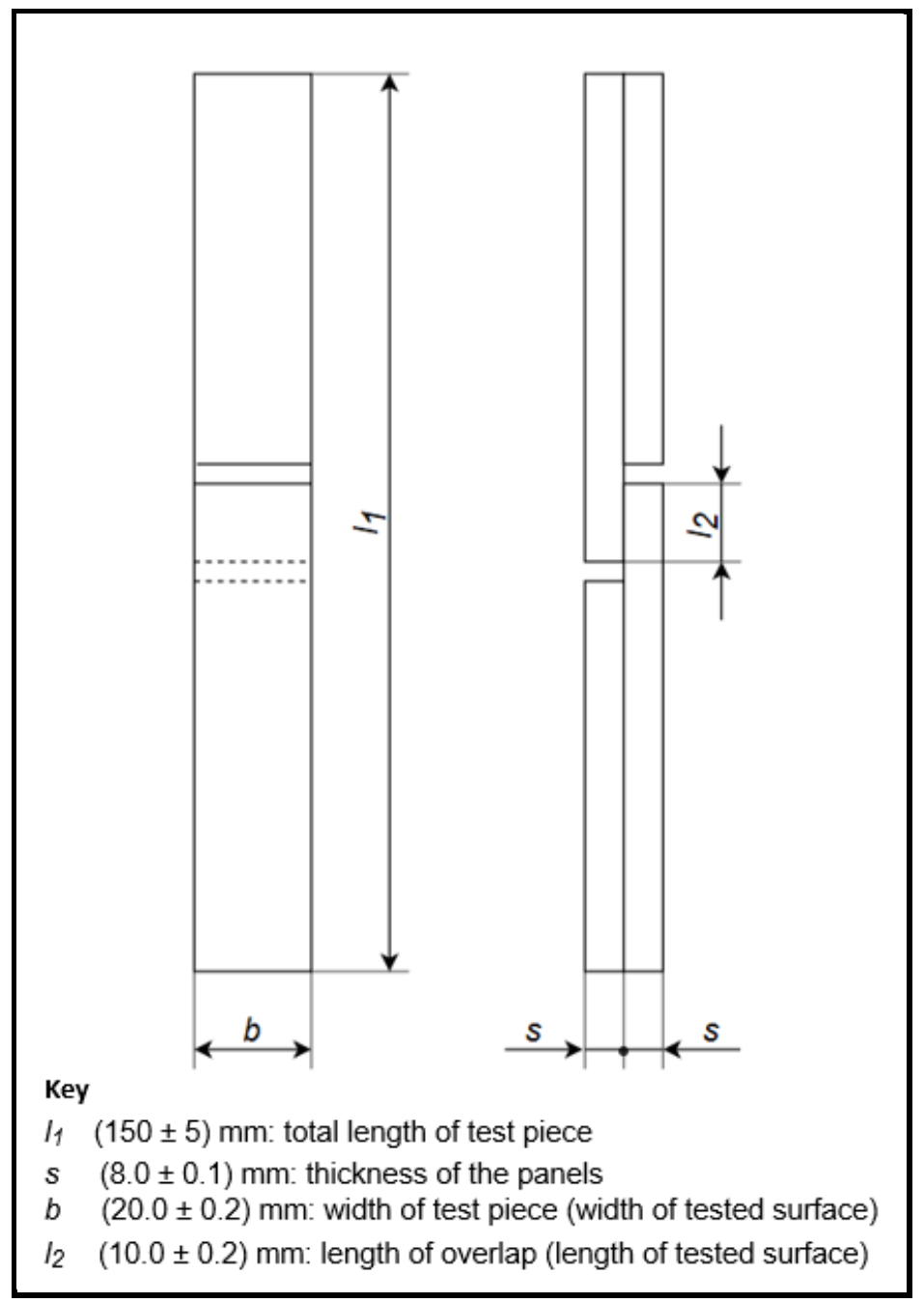

Fig. 5. Lap shear sample dimensions

Lap shear tensile testing was performed using a universal testing machine (AG100X, Shimadzu Corporation, Kyoto, Japan) testing rig fitted with a 100-kN load cell with a crosshead displacement rate of $1.5 \mathrm{~mm} / \mathrm{min}$. The data were processed using Trapezium $\mathrm{X}$ single cycle software (Version 1.5.1, Shimadzu Corporation, Kyoto, Japan). The lap shears had a minimum of $40 \mathrm{~mm}$ of each end clamped into the jaws of the testing rig before 
being loaded in tension until failure. The maximum force applied to reach failure was recorded. The tensile shear strength $(\tau)(\mathrm{MPa})$ was then calculated using Eq. 3:

$$
\tau=\frac{F_{\max }}{l_{2} b}
$$

where $F_{\max }$ is the applied maximum force $(\mathrm{N}), l_{2}$ is the length of the bonded test surface $(\mathrm{mm})$, and $b$ is the width of the bonded test surface $(\mathrm{mm})$.

\section{Treatability}

The treatability sample dimensions were $25 \mathrm{~mm} \times 8 \mathrm{~mm} \times 50 \mathrm{~mm}(\mathrm{~W} \times \mathrm{T} \times \mathrm{L})$. The samples were weighed before and after being immersed in an alkaline copper quaternary (ACQ) wood preservative solution $(0.7 \%$ concentration) for $2 \mathrm{~h}$. The 2 -h immersion time was deliberately chosen so that the treatment did not result in $100 \%$ cross section penetration, which would not have allowed comparisons of copper penetration differences between samples. The change in sample weight was used to determine the ACQ solution uptake in $\mathrm{L} / \mathrm{m}^{3}$. The treated samples were then dried and cut in half, and spot tests were conducted on the end-matched transverse surfaces to determine the preservative penetration (on one surface) and heartwood presence (on the other matching surface). Copper penetration was determined by a spot test according to the Australian and New Zealand standard AS/NZS 1605.2 (2018). The presence of heartwood on the end-matching face of the other half of the sample was determined according to AS/NZS 1605.2 (2018). Heartwood content overall was less than $1 \%$ and any heartwood containing pieces were not included in the data analysis. The image-processing software was used to quantify the copper penetration area in each sample.

\section{Statistical Analysis}

Statistical analysis was performed using the open-source statistical package RStudio (Studio Version 1.1.453, RStudio, Boston, MA, USA) (Baty et al. 2015) Both analysis of variance (ANOVA) and pairwise comparisons using Fisher's protected least significant difference (LSD) test were used. Both liquid and gas permeability data were transformed using natural log to stabilise the variance before conducing pairwise comparisons using Fisher's protected LSD test using GenStat (Version 19, VSN International, Hemel Hempstead, UK).

\section{RESULTS AND DISCUSSION}

\section{Permeability}

Results of the gas and liquid permeability tests are shown in Tables 2 and 3 and Figs. 6 and 7.

The differences between the drying groups in gas permeability were not significant (Tables 2 and 3). Considering combined surface and core test data, the high temperature drying resulted in a significantly lower liquid permeability compared to low temperature drying (Table 2). For combined data, there were no significant differences in liquid permeability between low temperature and continuous drying or between continuous and high temperature drying (Table 2). In all cases shown in Table 3 and Figs. 6 and 7, mean gas and liquid permeabilities were greatest with surface samples, compared to core samples. This result is most likely a consequence of the greater incidence of checking 
observed in surface samples compared to core samples. For gas permeability, there were no significant differences within or between groups for surface permeability compared to core permeability. However, surface liquid permeability was significantly greater compared to core liquid permeability for the continuous and high temperature dried samples (Table 3).

Table 2. Summary of Permeability Results for Each Drying Group (Combined surface and core data)

\begin{tabular}{|c|c|c|}
\hline Drying Group & $\begin{array}{c}\text { Mean Gas Permeability } \\
(\mathrm{mD})\end{array}$ & $\begin{array}{c}\text { Mean Liquid Permeability } \\
(\mathrm{mD})\end{array}$ \\
\hline $\begin{array}{c}\text { Low Temperature } \\
\text { Drying Schedule }\end{array}$ & $107^{\mathrm{a}}$ & $13.04^{\mathrm{a}}$ \\
\hline $\begin{array}{c}\text { Continuous Drying } \\
\text { Schedule }\end{array}$ & $96^{\mathrm{a}}$ & $12.98^{\mathrm{ab}}$ \\
\hline $\begin{array}{c}\text { High Temperature } \\
\text { Drying Schedule }\end{array}$ & $80^{\mathrm{a}}$ & $5.97^{\mathrm{b}}$ \\
\hline
\end{tabular}

Note: Means followed by the same letter in the same column are not significantly different $(0.05) . \mathrm{mD}=$ millidarcies.

Table 3. Summary of Permeability Results for Surface and Core Samples of Each Drying Group

\begin{tabular}{|c|c|c|c|}
\hline Drying Group & Surface or Core & $\begin{array}{c}\text { Mean Gas Permeability } \\
(\mathrm{mD})\end{array}$ & $\begin{array}{c}\text { Mean Liquid Permeability } \\
(\mathrm{mD})\end{array}$ \\
\hline $\begin{array}{c}\text { Low Temperature } \\
\text { Drying Schedule }\end{array}$ & Surface & $147^{\mathrm{a}}$ & $17^{\mathrm{abc}}$ \\
\cline { 2 - 4 } $\begin{array}{c}\text { Continuous Drying } \\
\text { Schedule }\end{array}$ & Core & $98^{\mathrm{a}}$ & $12^{\mathrm{a}}$ \\
\cline { 2 - 4 } & Corface & $104^{\mathrm{a}}$ & $16^{\mathrm{a}}$ \\
\hline $\begin{array}{c}\text { High Temperature } \\
\text { Drying Schedule }\end{array}$ & Surface & $88^{\mathrm{a}}$ & $9^{\mathrm{ab}}$ \\
\cline { 2 - 4 } & Core & $81^{\mathrm{a}}$ & $5^{\mathrm{c}}$ \\
\hline
\end{tabular}

Means followed by the same letter in the same column are not significantly different $(0.05)$. $\mathrm{mD}=$ millidarcies.

The greater mean permeability of low temperature schedule dried timber compared to high temperature schedule dried timber in this study is contrary to other studies which have shown the opposite result of a greater permeability with greater temperature drying (Booker and Evans 1994; Zhang and Cai 2008; Lande et al. 2010), although there are contradictory reports about the effects of drying method on wood permeability and treatability (Tarmian et al. 2020). The reasons presented for the reported trend of greater permeability with higher temperature drying include the effects of high temperature drying schedules on the wood microstructure, such as the collapse of thin-walled cells resulting in the creation of interstitial spaces; rupturing in pit torus, pit borders, and cell walls; creation of micro-checks caused by the high temperature drying process, improving liquid penetration; and mobilisation and dispersal of natural wood resin (Tiemann 1910; Weiss 1912; Booker and Evans 1994; Winandy et al. 2001; Zhang and Cai 2008; Lande et al. 2010). 


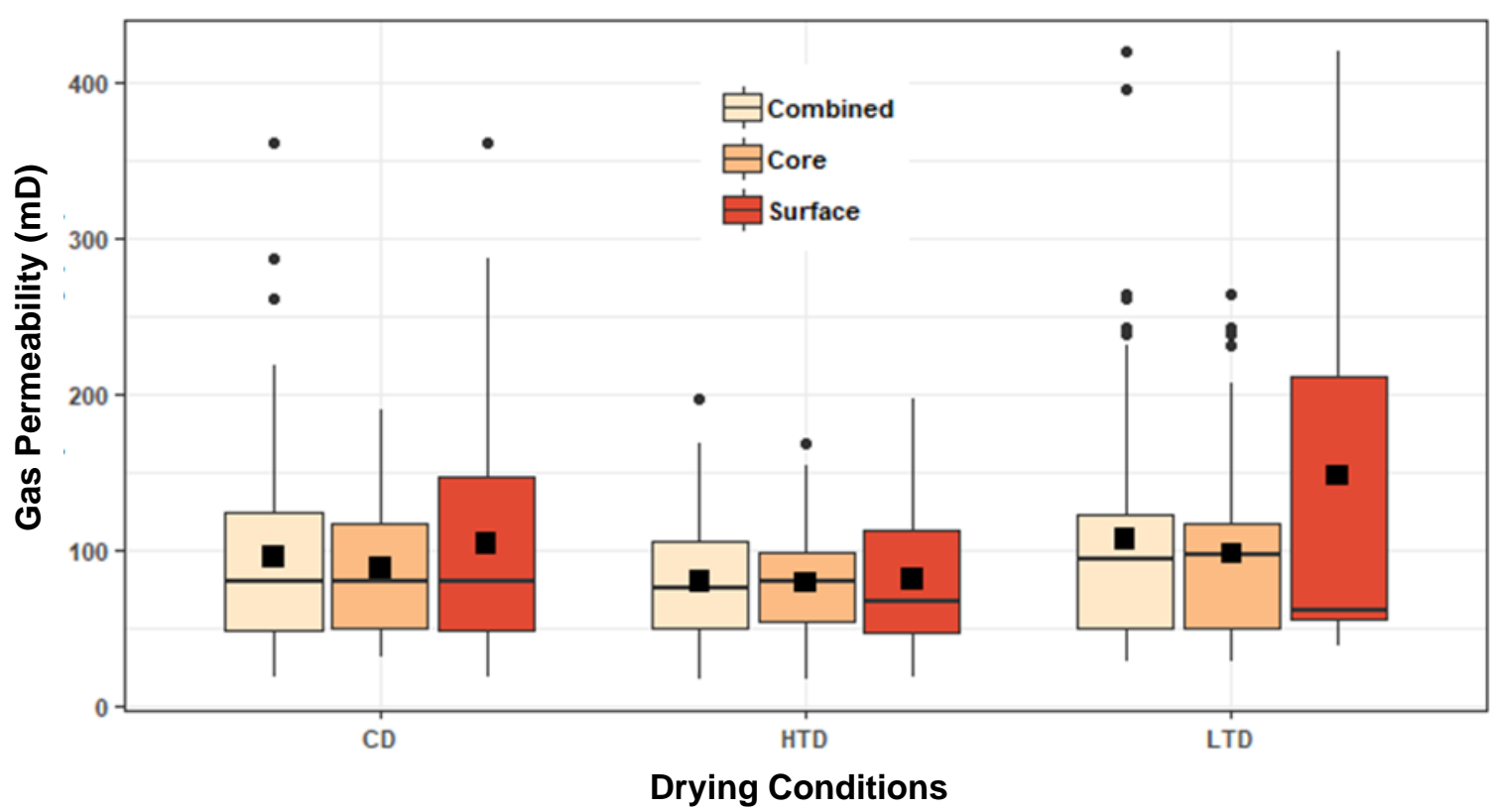

Fig. 6. Gas permeabilities of surface and core samples from each drying group ( $C D=$ Continuous Drying; HTD=High Temperature Drying; LTD=Low Temperature Drying)

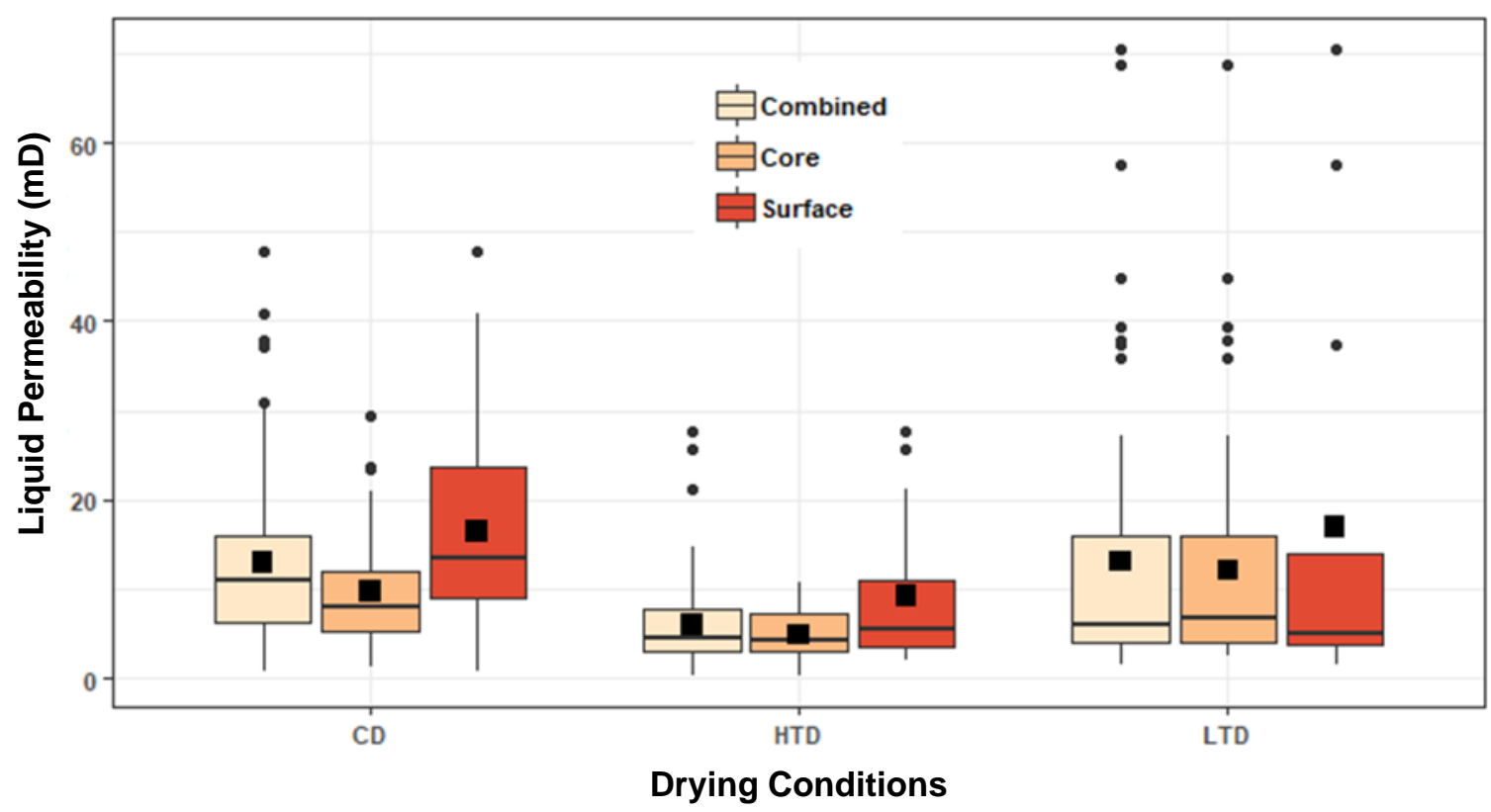

Fig. 7. Liquid permeabilities of surface and core samples from each drying group ( $C D=$ Continuous Drying; HTD=High Temperature Drying; LTD=Low Temperature Drying)

Even though, in this study, the low temperature drying resulted in the greatest mean gas and liquid permeabilities for the combined data and for the surface and core, it resulted in the lowest median surface gas and liquid permeabilities. Further investigations on the reasons for the differences in permeability between the different drying groups are warranted. These studies should include assessments on changes in wood anatomy and resin distribution caused by drying schedules that might influence permeability. 
Gas permeability was much greater than liquid permeability (for overall data, on average, approximately nine times greater). Due to greater viscosity, molecular size, and liquid-wood interactions, liquid permeability is usually much lower than gas permeability (Taghiyari 2012; Rezende et al. 2018; Leggate et al. 2019, 2020). There was also a significant positive relationship $\left(\mathrm{R}^{2}=0.68, \mathrm{p}<0.001\right)$ between gas and liquid permeabilities, as shown in Fig. 8. This result was consistent with other studies by Leggate et al. (2019, 2020), who also reported a significant positive relationship between the gas and liquid permeabilities of plantation grown southern pine from Queensland, Australia.

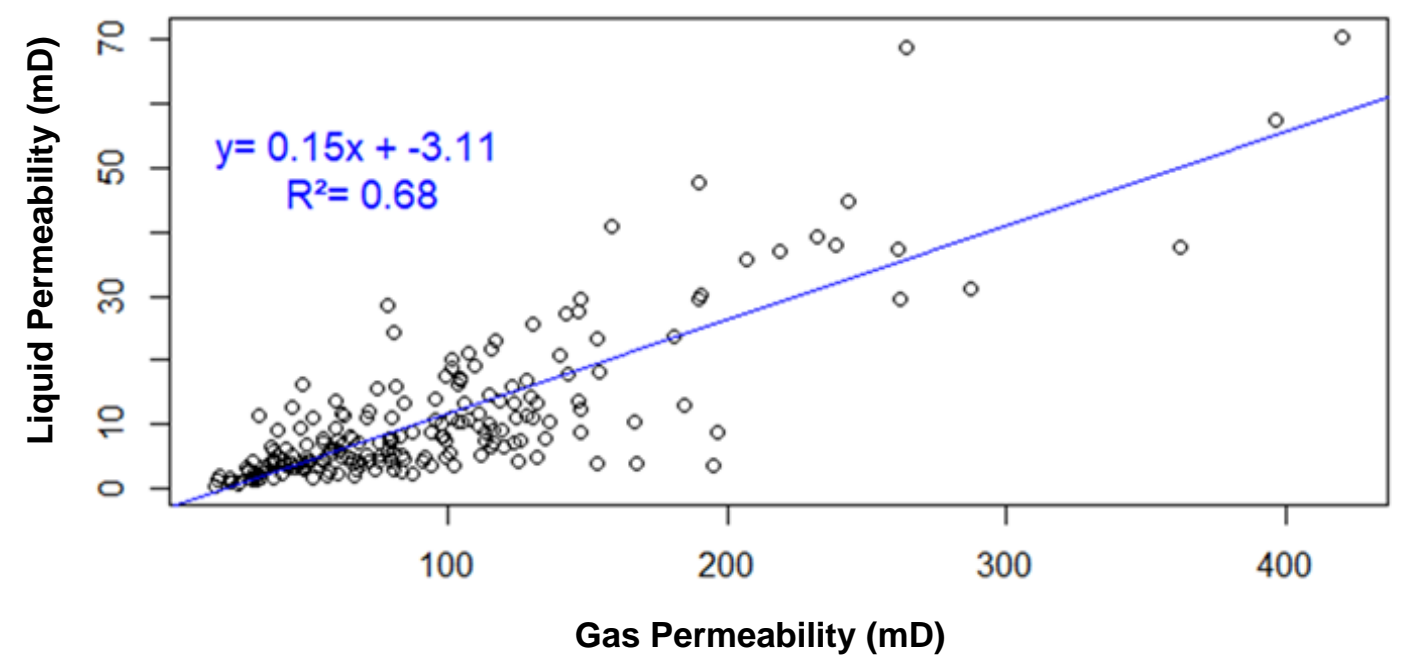

Fig. 8. Relationship between gas and liquid permeabilities

\section{Wettability}

Across all drying groups for all data combined, contact angles were significantly reduced, and therefore wettability increased, over the 10-s test time period ( $\mathrm{p}<0.001)$ (Table 4 and Figs. 9 and 10). This result reflected the typical wetting process, which includes the formation of a contact angle between the surface and the droplet, the spreading of the droplet on the surface, and then the penetration of the droplet into the sample (Leggate et al. 2020). However, different trends were observed for pre-machining versus post-machining, with the pre-machining samples having significantly greater contact angles for all data combined $(\mathrm{p}<0.001)$ and therefore lower wettabilities compared to the post-machining samples (Table 4). Additionally, pre-machining contact angles throughout the 10-s test time remained much greater, no less than $45^{\circ}$, whereas post machining contact angles decreased much faster, reaching $0^{\circ}$ in many cases very quickly (less than $3 \mathrm{~s}$ ) (Figs. 9 and 10). The increased wettability of the wood surface after machining is the reason that wood usually undergoes a surface machining process such as planing prior to gluing. Surface machining increases the wettability of the wood surface by activating the wood surface through the removal of extractives (which have migrated to the surface) and contaminants (e.g., dust and dirt) (Leggate et al. 2020). 
Table 4. Summary of Wettability Results (at $10 \mathrm{~s}$ of test time)

\begin{tabular}{|c|c|c|c|c|}
\hline Drying Group & Earlywood/Latewood & Machining Stage & $\begin{array}{l}\text { Mean Contact } \\
\text { Angle }\left({ }^{\circ}\right)^{*}\end{array}$ & Mean $K$-value \\
\hline \multirow{4}{*}{ Continuous } & \multirow{2}{*}{ Earlywood } & Pre-machining & $47(9)^{b}$ & 0.15 \\
\hline & & Post-machining & $0(0)^{\mathrm{c}}$ & 17.47 \\
\hline & \multirow{2}{*}{ Latewood } & Pre-machining & $50(7)^{\mathrm{b}}$ & 0.15 \\
\hline & & Post-machining & $8(14)^{c}$ & 0.46 \\
\hline \multirow{4}{*}{ High Temperature } & \multirow{2}{*}{ Earlywood } & Pre-machining & $48(5)^{b}$ & 0.16 \\
\hline & & Post-machining & $0(0)^{c}$ & 6.66 \\
\hline & \multirow{2}{*}{ Latewood } & Pre-machining & $62(11)^{a}$ & 0.12 \\
\hline & & Post-machining & $5(8)^{c}$ & 0.58 \\
\hline \multirow{4}{*}{ Low Temperature } & \multirow{2}{*}{ Earlywood } & Pre-machining & $45(10)^{b}$ & 0.18 \\
\hline & & Post-machining & $0(0)^{c}$ & 12.43 \\
\hline & \multirow{2}{*}{ Latewood } & Pre-machining & $66(16)^{\mathrm{a}}$ & 0.08 \\
\hline & & Post-machining & $7(12)^{c}$ & 0.61 \\
\hline
\end{tabular}

Note: Means followed by the same letter in the same column are not significantly different $(0.05)$.

* Standard deviations are presented in parentheses.

The contact angles of earlywood were overall significantly lower than those of latewood for both the pre- and post-machining groups ( $<<0.01$ for pre-machining; $\mathrm{p}<$ 0.05 for post-machining). This result was in accordance with another recent study on southern pine by Leggate $e t$ al. (2020) and also other studies showing that pine earlywood has greater wettability and is easier to glue compared to latewood (Herczeg 1965; Hse 1968; Scheikl and Dunky 1998). The greater wettability of earlywood is related to its lower density, greater tracheid lumen diameters, and greater porosity compared to latewood (Scheikl and Dunky 1998; Frihart 2013).

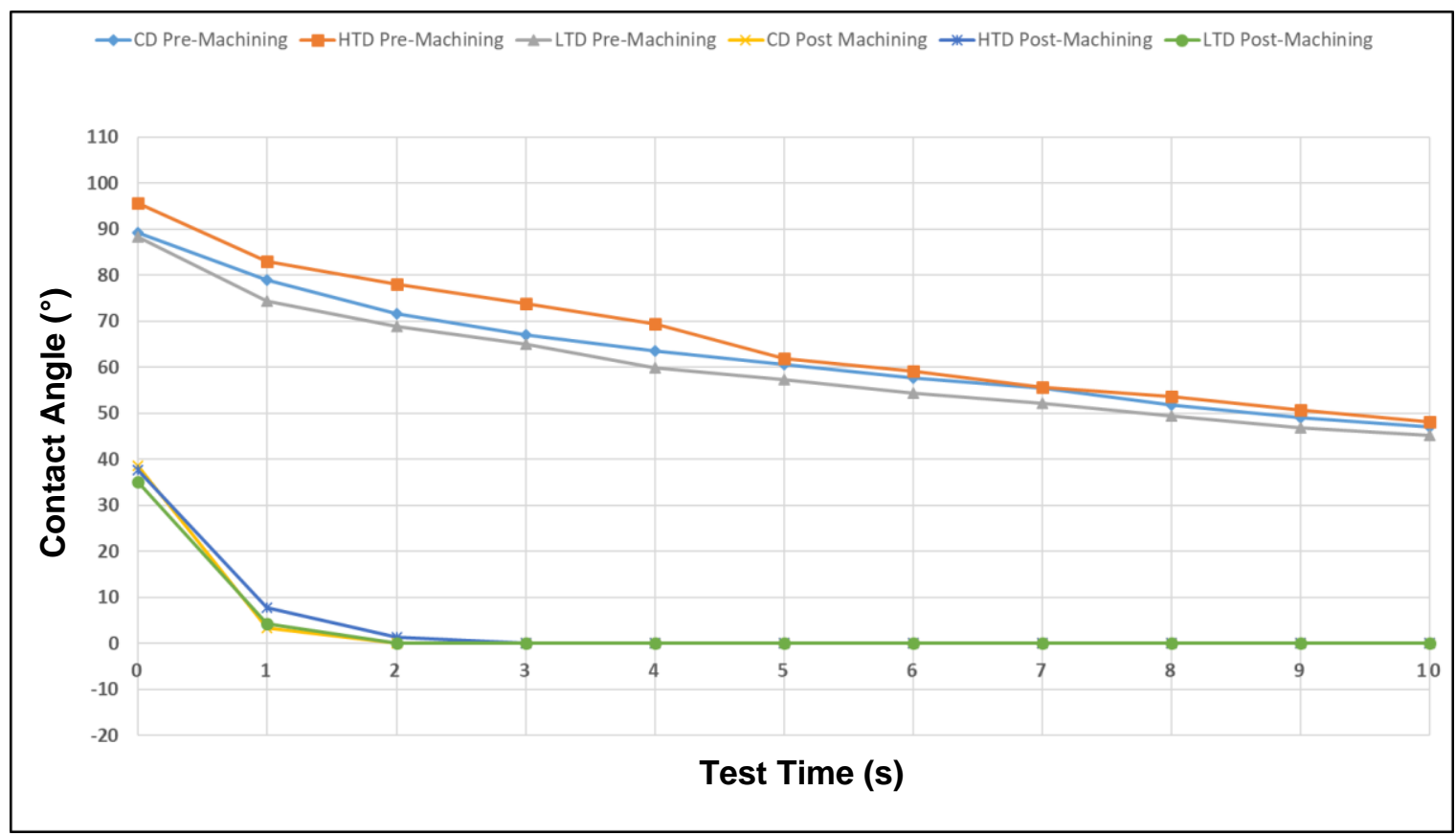

Fig. 9. Change in contact angle with time for earlywood: before and after surface machining ( $C D=$ Continuous Drying; HTD=High Temperature Drying; LTD=Low Temperature Drying) 


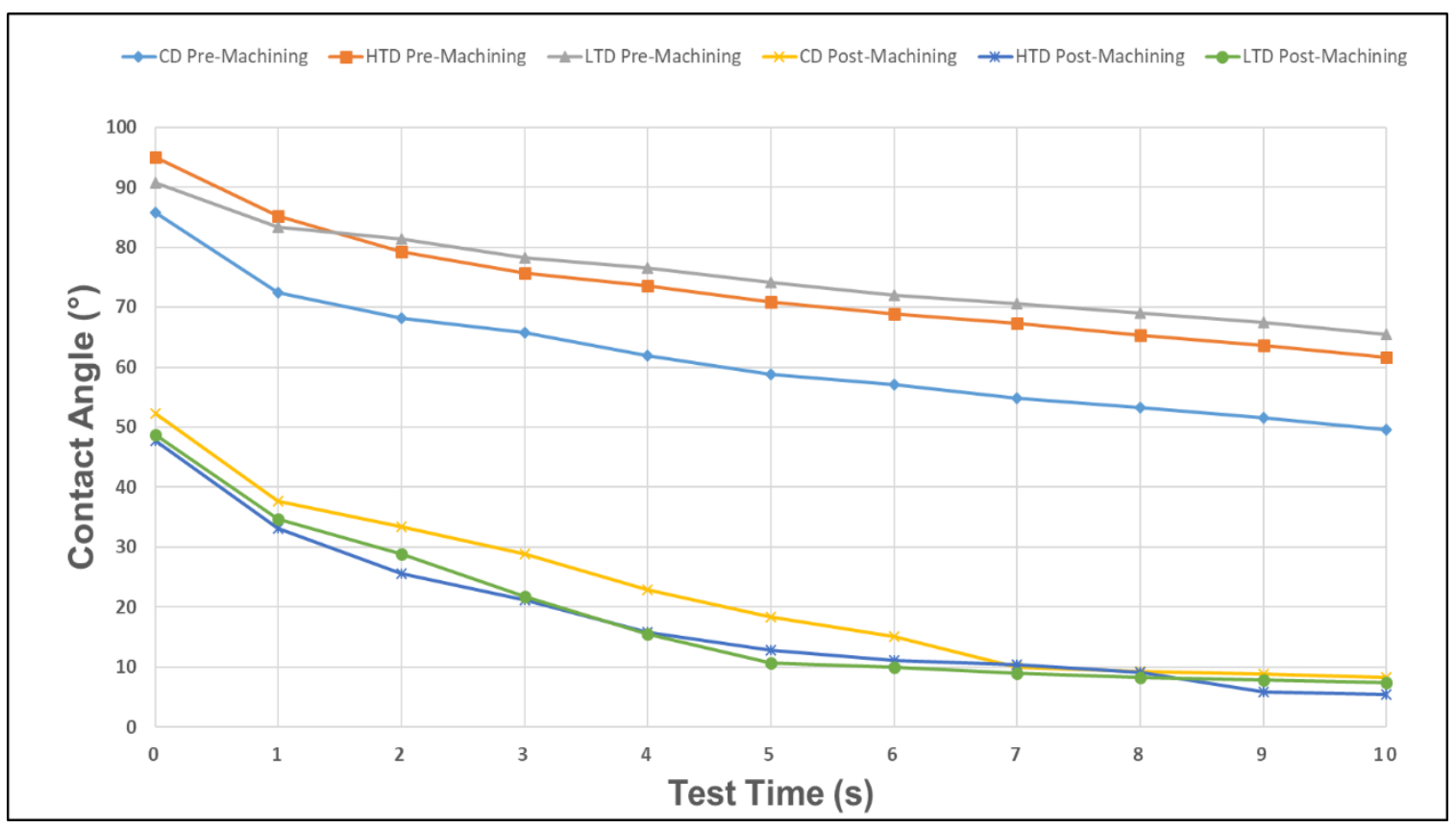

Fig. 10. Change in contact angle with time for latewood: before and after surface machining ( $C D=$ Continuous Drying; HTD=High Temperature Drying; LTD=Low Temperature Drying)

In terms of drying group differences in wettability based on contact angle data, the trends were different for earlywood and latewood and for pre- and post-machining. For pre-machining earlywood at $10 \mathrm{~s}$ of test time, the ranking of wettability results from greatest to lowest was as follows: low temperature drying, continuous drying, and high temperature drying. For post-machining earlywood at $10 \mathrm{~s}$ of test time, there were no differences between drying groups, with all drying groups reaching a mean contact angle of $0^{\circ}$. However, across the 10 -s test time, the high temperature drying group remained at a greater contact angle for longer, compared to the low temperature and continuous drying groups (Fig. 9). The lower wettability of higher temperature dried wood is consistent with other studies, which have shown that wood surfaces that have been exposed to a high temperature condition (including higher temperature drying) can experience surface inactivation or reduced wettability (Sernek 2002; Šrnek et al. 2004). The better wettability of continuous dried wood (for earlywood) compared to high temperature schedule dried wood is a positive finding for companies looking to convert from high temperature to continuous drying kilns. Positive relationships have been shown between wettability and improved bond quality (Sernek 2002; Aydin 2004; Hernández and Cool 2008; Kläusler et al. 2014). However, different trends for the effect of drying schedules on wettability were observed for latewood. For pre-machining latewood at $10 \mathrm{~s}$ of test time, the ranking of wettability results (based on contact angle data) from greatest to lowest was as follows: continuous drying, high temperature drying, and low temperature, with continuous drying resulting in significantly greater wettability compared to low and high temperature drying (Table 4 and Fig. 10). For post-machining latewood at $10 \mathrm{~s}$ of test time, the ranking of wettability results (based on contact angle data) from highest to lowest was as follows: high temperature drying, low temperature drying, and continuous drying (Table 4 and Fig. 
10). However, the differences between the drying groups for post-machining latewood contact angles were not significant (Table 4).

The $K$-values shown in Table 4 represent the rate at which a liquid (in this case water) spreads and penetrates into the porous structure of wood (Huang et al. 2012; Leggate et al. 2020). By knowing the $K$-value, the spreading and penetration for a given liquid-solid system can be quantified and compared (Huang et al. 2012; Leggate et al. 2020). Greater $K$-values indicate that the contact angle reaches equilibrium more rapidly, and the liquid penetrates and spreads faster (increased wetting) (Huang et al. 2012; Leggate et al. 2020). The $K$-values were generally consistent with the contact angle data, with greater $K$-values (and therefore increased wettability of the surface) after surface machining. The $K$-values of earlywood were also greater than for latewood (Table 4). The $K$-value rankings for each drying group also matched the contact angle rankings with one exception: For postmachining latewood, low temperature drying produced a greater $K$-value compared to the other two drying groups.

\section{Gluability}

Results for tensile shear strength of the lap shear samples are shown in Tables 5 and 6 and Fig. 11.

Table 5. Summary of Tensile Shear Strength Results for Each Drying Group (Combined surface and core data)

\begin{tabular}{|c|c|}
\hline Drying Group & Mean Tensile Shear Strength $\left(\mathrm{N} / \mathrm{mm}^{2}\right)$ \\
\hline Low Temperature Drying Schedule & $11.18^{\mathrm{a}}$ \\
\hline Continuous Drying Schedule & $11.99^{\mathrm{a}}$ \\
\hline High Temperature Drying Schedule & $11.49^{\mathrm{a}}$ \\
\hline
\end{tabular}

Note: Means followed by the same letter in the same column are not significantly different $(0.05)$.

Table 6. Summary of Tensile Shear Strength Results for Surface and Core of Each Drying Group

\begin{tabular}{|c|c|c|}
\hline \multirow{2}{*}{ Drying Group } & Surface or Core & $\begin{array}{c}\text { Mean Tensile Shear Strength } \\
\left(\mathrm{N} / \mathrm{mm}^{2}\right)\end{array}$ \\
\hline \multirow{2}{*}{$\begin{array}{c}\text { Low Temperature } \\
\text { Drying Schedule }\end{array}$} & Surface & $12.24^{\mathrm{a}}$ \\
\cline { 2 - 3 } & Core & $10.13^{\mathrm{b}}$ \\
\hline $\begin{array}{c}\text { Continuous } \\
\text { Drying Schedule }\end{array}$ & Surface & $12.11^{\mathrm{a}}$ \\
\cline { 2 - 3 } & Core & $11.87^{\mathrm{a}}$ \\
\hline \multirow{2}{*}{$\begin{array}{c}\text { High Temperature } \\
\text { Drying Schedule }\end{array}$} & Surface & $11.23^{\mathrm{ab}}$ \\
\cline { 2 - 3 } & Core & $11.74^{\mathrm{ab}}$ \\
\hline
\end{tabular}

Note: Means followed by the same letter in the same column are not significantly different (0.05). 


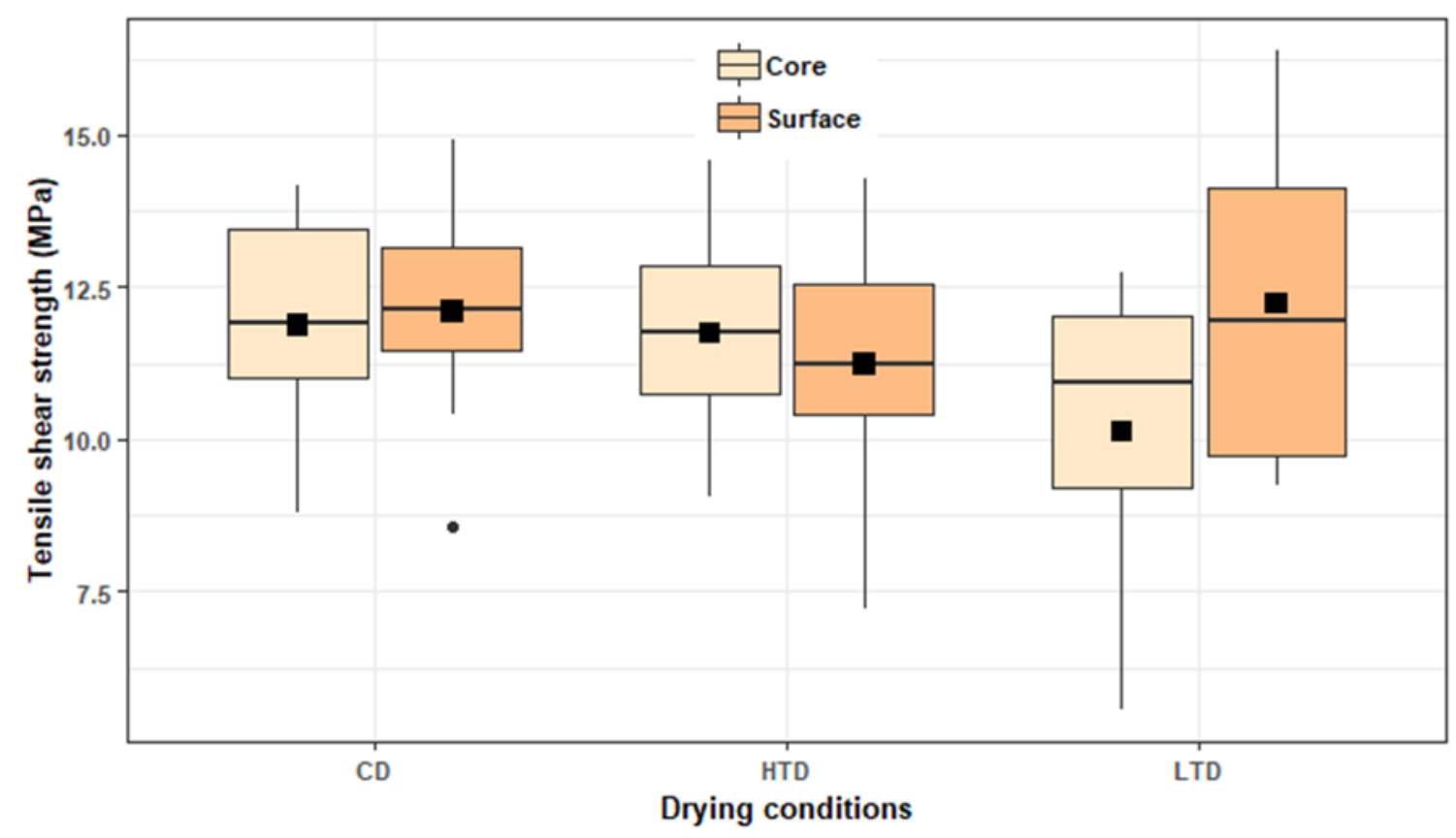

Fig. 11. Tensile shear strength results of lap shear samples from each drying group ( $C D=$ Continuous Drying; HTD=High Temperature Drying; LTD=Low Temperature Drying)

As shown in Table 5, for combined surface and core data, there was no significant effect of drying type on the tensile shear strength of lap shear samples. However, the continuous drying group had the greatest mean tensile shear strength. Differences between surface and core samples were not significant with the exception of the low temperature drying group, where the surface samples had a significantly greater shear strength than the core samples (Table 6). This result could possibly be caused by greater resin content in the core compared to the surface of low temperature dried wood, where the resins may not have been mobilised towards the surface due to the low temperatures used. However, resin content and distribution were not assessed in this study.

\section{Treatability}

Results for copper penetration and preservative uptake are shown in Tables 7 and 8 and in Figs. 12 and 13. As shown in Table 7, for combined surface and core samples, the continuous drying schedule resulted in significantly greater preservative uptake compared to the other two drying groups and significantly greater copper penetration compared to low temperature drying. There was no significant difference between continuous drying and high temperature drying for copper penetration. The lowest mean preservative uptake and copper penetration resulted from low temperature drying. Table 8 shows that within drying groups there were no significant differences between surface and core samples in preservative uptake and copper penetration. However, with the exception of the continuous drying group, surface samples had greater mean preservative uptake and copper penetration compared to core samples. The greater treatability of the surface samples in the low temperature and high temperature dried groups is most likely related to the greater frequency of surface checking observed in these samples, which would increase the number and size of pathways for fluid flow through the samples. The surface samples also had the greatest permeability (discussed above). However, apart from this similarity, the rankings for permeability (mean values) for the three different drying groups did not match the 
rankings for mean preservative uptake and copper penetration. For example, low temperature drying resulted in the greatest mean gas and liquid permeabilities but the lowest mean preservative uptake and copper penetration.

Table 7. Summary of Results for Copper Penetration and Preservative Uptake for Each Drying Group for Combined Surface and Core Data

\begin{tabular}{|c|c|c|}
\hline Drying Group & $\begin{array}{c}\text { Mean Copper Penetration Area } \\
(\%)\end{array}$ & $\begin{array}{c}\text { Mean Preservative Uptake } \\
\left(\mathrm{L} / \mathrm{m}^{3}\right)\end{array}$ \\
\hline $\begin{array}{c}\text { Low Temperature } \\
\text { Drying Schedule }\end{array}$ & $7.49^{\mathrm{b}}$ & $155.53^{\mathrm{b}}$ \\
\hline $\begin{array}{c}\text { Continuous } \\
\text { Drying Schedule }\end{array}$ & $14.8^{\mathrm{a}}$ & $199.08^{\mathrm{a}}$ \\
\hline $\begin{array}{c}\text { High Temperature } \\
\text { Drying Schedule }\end{array}$ & $14.47^{\mathrm{a}}$ & $172.35^{\mathrm{b}}$ \\
\hline
\end{tabular}

Means followed by the same letter in the same column are not significantly different $(0.05)$.

Table 8. Summary of Results for Copper Penetration and Preservative Uptake for Surface and Core Samples for Each Drying Group

\begin{tabular}{|c|c|c|c|}
\hline Drying Group & Surface or Core & $\begin{array}{c}\text { Mean Copper Penetration } \\
\text { Area (\%) }\end{array}$ & $\begin{array}{c}\text { Mean Preservative Uptake } \\
\left(\mathrm{L} / \mathrm{m}^{3}\right)\end{array}$ \\
\hline \multirow{2}{*}{$\begin{array}{c}\text { Low Temperature } \\
\text { Drying Schedule }\end{array}$} & Surface & $7.54^{\mathrm{b}}$ & $161.8^{\mathrm{bc}}$ \\
\cline { 2 - 4 } & Core & $7.43^{\mathrm{b}}$ & $148.86^{\mathrm{c}}$ \\
\hline $\begin{array}{c}\text { Continuous } \\
\text { Drying Schedule }\end{array}$ & Surface & $13.4^{\mathrm{a}}$ & $198.72^{\mathrm{a}}$ \\
\cline { 2 - 4 } & Core & $16.31^{\mathrm{a}}$ & $199.48^{\mathrm{a}}$ \\
\hline \multirow{2}{*}{$\begin{array}{c}\text { High Temperature } \\
\text { Drying Schedule }\end{array}$} & Surface & $16^{\mathrm{a}}$ & $190.89^{\mathrm{ab}}$ \\
\cline { 2 - 4 } & Core & $13.09^{\mathrm{a}}$ & $155.66^{\mathrm{bc}}$ \\
\hline
\end{tabular}

Means followed by the same letter in the same column are not significantly different $(0.05)$.

Usually, permeability is regarded as closely related to treatability; however, some studies have shown that this is not always the case (Prak 1970). Prak (1970) explained that high permeability values indicate that fluid or gas passage through the wood is easy, but they do not necessarily mean that all voids are filled readily with a fluid-some portion of the specimen may be even almost inaccessible, while the whole specimen appears highly permeable. Another reason for the finding of a limited relationship between permeability and treatability in the current study is that only radial permeability was measured, whereas the treatability results reflect liquid movement into the wood in all directions. The results for treatability better matched the expected results based on other studies, compared to the permeability results. As explained above, many studies have reported lower treatability and permeability with wood that has been low temperature dried compared to wood that has been high temperature dried. Differences in treatability and permeability between the drying groups are likely explained by the effects of the different drying conditions on wood 
anatomical structure, including the presence of interstitial spaces and micro-checks, 2) pit aspiration and integrity of pit membranes and cell walls, and 3) wood resin distribution. Further studies into the differences between the three different drying types in terms of their effects on wood anatomy and resin distribution would likely help to elucidate the reasons for the differences in permeability and treatability.

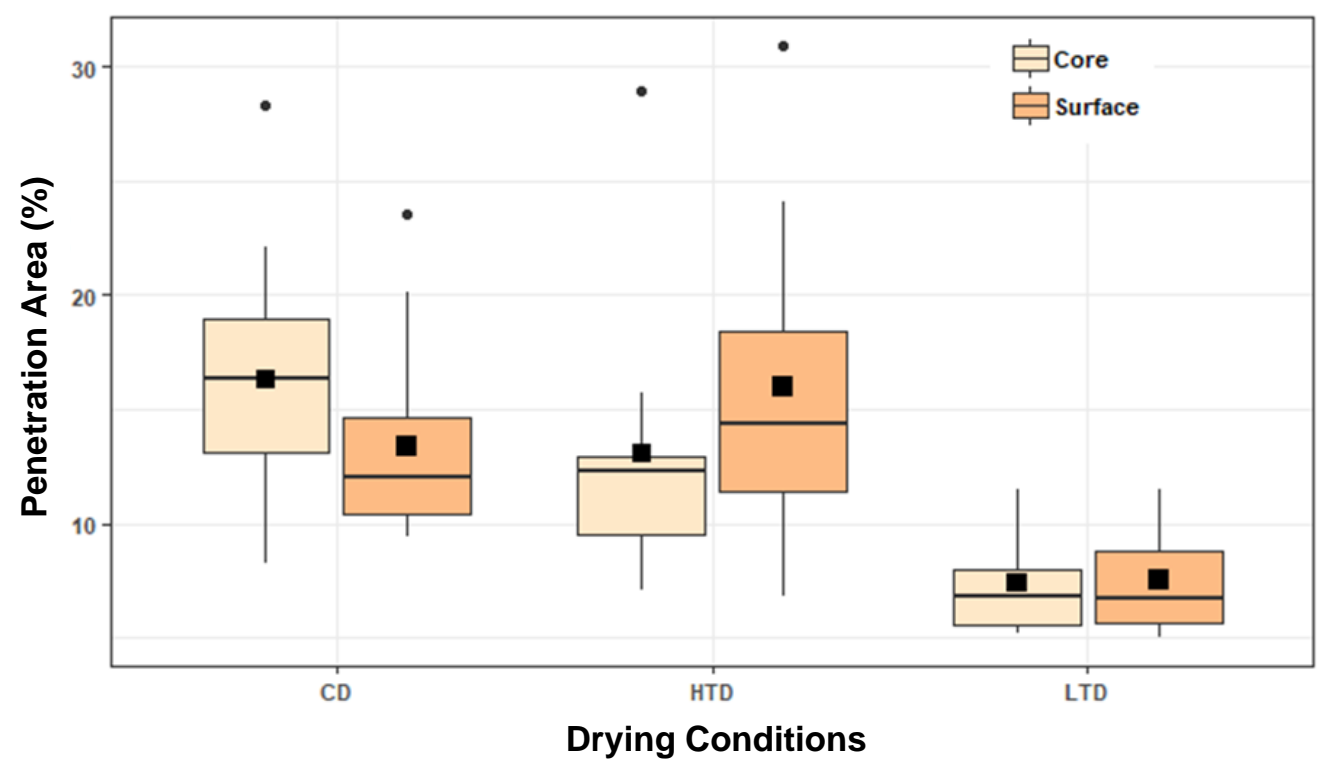

Fig. 12. Copper penetration in surface and core samples of each drying group $(C D=$ Continuous Drying; HTD=High Temperature Drying; LTD=Low Temperature Drying)

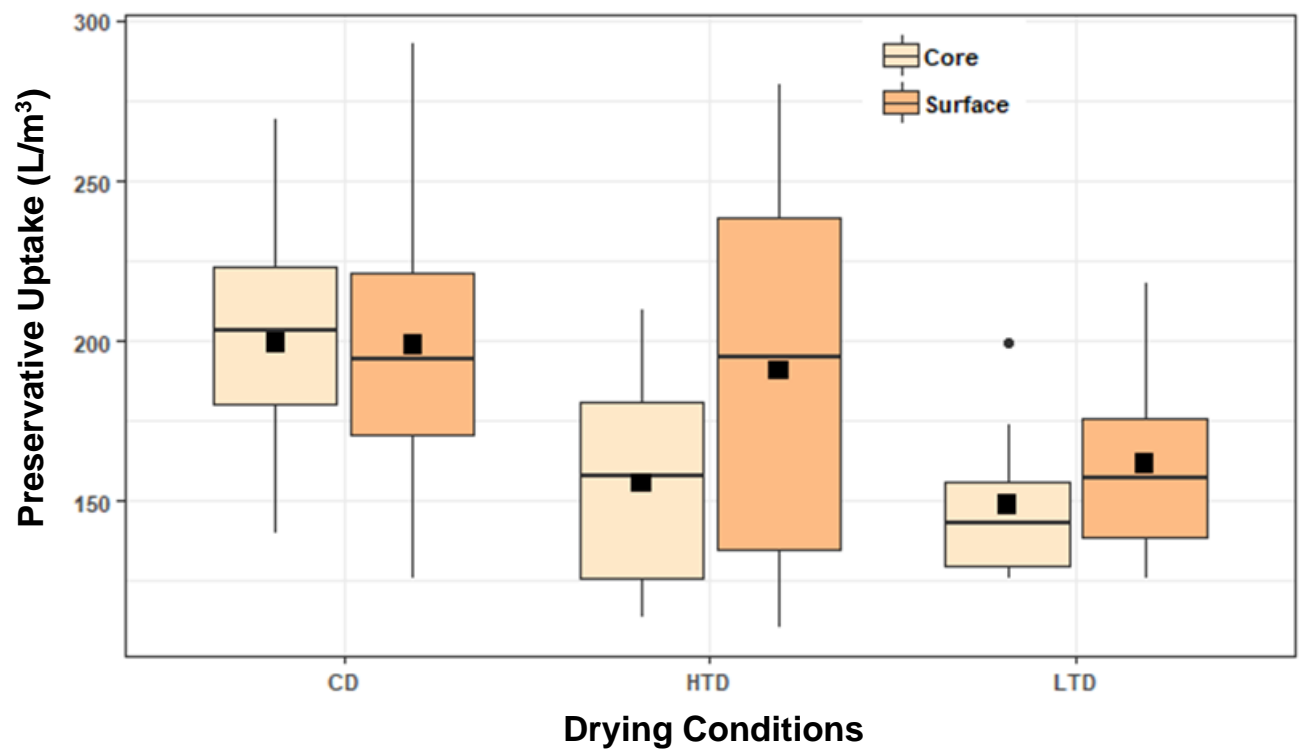

Fig. 13. Preservative uptakes in surface and core samples of each drying group $(C D=$ Continuous Drying; HTD=High Temperature Drying; LTD=Low Temperature Drying) 


\section{CONCLUSIONS}

1. For combined surface and core assessments, the greatest mean gas and liquid radial permeabilities were exhibited by the low temperature drying group, followed by the continuous drying group, and then the high temperature drying group, which exhibited the lowest mean gas and liquid radial permeabilities. However, the differences between the groups in gas radial permeability were not significant. For combined surface and core assessments, the high temperature drying resulted in significantly lower liquid radial permeability compared to low temperature drying; however, there were no significant differences in liquid radial permeability between low temperature drying and continuous drying or between continuous drying and high temperature drying. In most cases, surface samples had greater gas and liquid radial permeabilities compared to core samples. This result could be attributed to the greater incidence of surface checking in the surface samples. There was a significant positive relationship between gas and liquid radial permeabilities.

2. Surface machining significantly increased the wood wettability, and earlywood had significantly greater wettability than latewood. Rankings in wettability between drying groups varied with pre- and post-machining, as well as for earlywood and latewood. Comparing post-machining $K$-values for earlywood, continuous drying resulted in greater wettability compared to high temperature drying and low temperature drying. However, for post-machining latewood, the low temperature drying schedule resulted in the greatest wettability.

3. The highest tensile shear strength for lap shear samples resulted from the continuous drying schedule; however, differences between drying groups were not significant.

4. For treatability, continuous drying resulted in greater preservative uptake and copper penetration compared to the high temperature and low temperature drying schedules, although there was no significant difference in copper penetration between the continuous and high temperature drying schedules.

5. Overall, the results revealed better outcomes for the continuous drying schedule compared to the high temperature drying schedule for permeability, wettability, gluability, and treatability. This result is encouraging for companies looking to switch from drying with conventional high temperature batch kilns to continuous drying kilns.

\section{ACKNOWLEDGMENTS}

The authors are particularly grateful for the technical support of Mrs. Rica Minnett, Mr. Stuart Meldrum, Mr. Andrew Outhwaite, Mr. Chuang Miao, Mr. Jack Dorries, and Dr. Maryam Shirmohammadi with the preparation, processing, and testing of wood samples. Kerri Chandra is thanked for her assistance with statistical analysis. Mr. Tomas Leggate is acknowledged for his assistance with diagram preparation. The support provided by the Queensland Government, Department of Agriculture and Fisheries (DAF), through the provision of the unique facilities located at the Salisbury Research Facility is acknowledged as critical to facilitate studies of this nature. The authors are also grateful to Hyne Timber, in particular Dr. Henri Bailleres, for the supply of the timber for this project. Mr. Rod Vella from Jowat Universal Adhesives Australia Pty Ltd is also thanked for the 
provision of the adhesives used in the study. The authors also acknowledge the Australian Research Council and the Centre for Future Timber Structures for the funding support provided for this research.

\section{REFERENCES CITED}

Ahmed, S. A., Sehlstedt-Persson, M., Karlsson, O., and Morén, T. (2012). “Uneven distribution of preservative in kiln-dried sapwood lumber of Scots pine: Impact of wood structure and resin allocation," Holzforschung 66(2), 251-258. DOI:

10.1515/HF.2011.126

Ahmed, S. A., Hansson, L., and Morén, T. (2013). "Distribution of preservatives in thermally modified Scots pine and Norway spruce sapwood," Wood Science and Technology 47, 499-513. DOI: 10.1007/s00226-012-0509-4

AS/NZS 1605.2 (2018). "Methods for sampling and analyzing timber preservatives and preservative-treated timber. Part 2: Determination of preservative penetration by spot test," Standards Australia, Sydney, Australia.

Aydin, İ. (2004). "Activation of wood surfaces for glue bonds by mechanical pretreatment and its effects on some properties of veneer surfaces and plywood panels," Applied Surface Science 233(1-4), 268-274. DOI: 10.1016/j.apsusc.2004.03.230

Bamber, R. K. (1972). "The formation and permeability of interstitial spaces in the sapwood of some Pinus species," Journal of the Institute of Wood Science 6(2), 3638.

Baty, F., Ritz, C., Charles, S., Brutsche, M., Flandrois, J.-P., and Delignette-Muller, M.L. (2015). "A toolbox for nonlinear regression in R: The package nlstools," Journal of Statistical Software 66(5), 1-21. DOI: 10.18637/jss.v066.i05

Booker, R. E. (1990). "Changes in transverse wood permeability during the drying of Dacrydium cupressinum and Pinus radiata," New Zealand Journal of Forestry Science 20(2), 231-244

Booker, R. E., and Evans, J. M. (1994). "The effect of drying schedule on the radial permeability of Pinus radiata D. Don," Holz als Roh- und Werkstoff 52, 150-156. DOI: 10.1007/BF02615211

BS EN 205 (2016). "Adhesives. Wood adhesives for non-structural applications. Determination of tensile shear strength of lap joints," British Standards Institution, London, UK.

Burch, C. P. (2015). Adhesion Fundamentals in Spotted Gum (Corymbia spp.), Master's Thesis, Virginia Polytechnic Institute and State University, Blacksburg, VA, USA.

Comstock, G. L. (1968). Physical and Structural Aspects of the Longitudinal Permeability of Wood, Ph.D. Dissertation, State University of New York, Syracuse, NY, USA.

Fogg, P. J. (1968). Longitudinal Air Permeability of Southern Pine Wood, Ph.D. Dissertation, Louisiana State University, Baton Rouge, LA, USA.

Friday Offcuts. (2011). "NZ's first operational continuous timber drying kiln," (https://fridayoffcuts.com/dsp_article.cfm?id=435\&aid=4374), Accessed 5 October 2020.

Frihart, C. R. (2013). "Wood adhesion and adhesives," in: Handbook of Wood Chemistry and Wood Composites, ${ }^{\text {nd }}$ Edition, R. M. Rowell (ed.), CRC Press, Boca Raton, FL, USA. DOI: $10.1201 / \mathrm{b} 12487$ 
Hansmann, C., Gindl, W., Wimmer, R., and Teischinger, A. (2002). "Permeability of wood - A review," Wood Research 47(4), 1-16.

Herczeg, A. (1965). "Wettability of wood," Forest Products Journal 15, 499-505.

Hernández, R. E., and Cool, J. (2008). "Evaluation of three surfacing methods on paper birch wood in relation to water- and solvent-borne coating performance," Wood and Fiber Science 40(3), 459-469.

Hovanec, D. (2015). Effect of Wood Characteristics on Adhesive Bond Quality of Yellowpoplar for Use in Cross-laminated Timbers, Master's Thesis, West Virginia University, Morgantown, WV, USA.

Hse, C. Y. (1968). "Gluability of southern pine earlywood and latewood," Forest Products Journal 18(12), 32-36.

Huang, X., Kocaefe, D., Boluk, Y., Kocaefe, Y., and Pichette, A. (2012). "Effect of surface preparation on the wettability of heat-treated jack pine wood surface by different liquids," European Journal of Wood and Wood Products 70, 711-717. DOI: 10.1007/s00107-012-0605-Z

Jewell, R., Mitchell, P. H., and Kutscha, N. P. (1990). "Species effects on the penetration of CCA in southern pine lumber," Proceedings of the Annual Meeting of the American Wood Preservers' Association 6(86), 22-30.

Kläusler, O, Rehm, K., Elstermann, F., and Niemz, P. (2014). "Influence of wood machining on tensile shear strength and wood failure percentage of one-component polyurethane bonded wooden joints after wetting," International Wood Products Journal 5(1), 18-26. DOI: 10.1179/2042645313Y.0000000039

Kučerová, I. (2012). "Methods to measure the penetration of consolidant solutions into 'dry' wood," Journal of Cultural Heritage 13(3), S191-S195. DOI: 10.1016/j.culher.2012.04.012

Kumar, C., and Redman, A. (2019). Impact of Continuous Drying on Key Production and Performance Criteria of Engineered Wood Structural Elements, Literature review, Department of Agriculture and Fisheries, Queensland, Australia.

Lamour, G., Hamraoui, A., Buvailo, A., Xing, Y., Keuleyan, S., Prakash, V., EftekhariBafrooei, A., and Borguet, E. (2010). "Contact angle measurements using a simplified experimental setup," Journal of Chemical Education 87(12), 1403-1407. DOI: $10.1021 / \mathrm{ed} 100468 \mathrm{u}$

Lande, S., Høibø, O., and Larnøy, E. (2010). "Variation in treatability of Scots pine (Pinus sylvestris) by the chemical modification agent furfuryl alcohol dissolved in water," Wood Science and Technology 44, 105-118. DOI:10.1007/s00226-009-0272-3

Lebow, S., Hatfield, C., and Halverson, S. (2006). "Effect of source, drying method and treatment schedule on treatability of red pine," in: Proceedings: One Hundred Second Annual Meeting of the American Wood-preservers' Association, Austin, TX, USA, pp. 39-43.

Lee, M.-G., Lu, J., Jiang, J., and Kang. H.-Y. (2008). "Effect of drying methods on longitudinal liquid permeability of Korean pine (Pinus koraiensis Sieb.et Zucc.)," Mokchae Konghak 36(5), 49-55.

Leggate, W., McGavin, R. L., Miao, C., Outhwaite, A, Chandra, K., Dorries, J., Kumar, C., and Knackstedt, M. (2020). "The influence of mechanical surface preparation methods on southern pine and spotted gum wood properties: Wettability and permeability," BioResources 15(4), 8554-8576. DOI: 10.15376/biores.15.4.85548576

Leggate, W., Redman, A., Wood, J., Bailleres, H., and Lee, D. J. (2019). "Radial 
permeability of the hybrid pine (Pinus elliottii $\times$ Pinus caribaea) in Australia," BioResources 14(2), 4358-4372. DOI: 10.15376/biores.14.2.4358-4372.

Milota, M. R., Tschernitz, J. L., Verrill, S. P., and Mianowski, T. (1995). "Gas permeability of plantation loblolly pine," Wood and Fiber Science 27(1), 34-40.

Navickas, P., Karpavičiūtè, S., and Albrektas, D. (2015). "Effect of heat treatment on wettability and MOE of pine and spruce wood," Materials Science 21(3), 400-404. DOI: $10.5755 /$ j01.ms.21.3.7304.

Oliveira, L., and Lazarescu, C. (2018). Continuous Drying of Softwood Dimension Lumber (Progress Report), FPInnovations, Vancouver, Canada.

Prak, A. L. (1970). "Unsteady-state gas permeability of wood," Wood Science and Technology 4, 50-69. DOI: 10.1007/BF00356237

Qin, Z., Gao, Q., Zhang, S., and Li, J. (2014). "Surface free energy and dynamic wettability of differently machined poplar woods," BioResources 9(2), 3088-3103. DOI: $10.15376 /$ biores.9.2.3088-3103

Redman, A. L. (2017). Modelling of Vacuum Drying of Australian Hardwood Species, Ph.D. Dissertation, Queensland University of Technology, Brisbane, Australia.

Rezende, R. N., Lima, J. T., de Ramos e Paula, L. E., Hein, P. R. G., and da Silva, J. R. M. (2018). "Wood permeability in Eucalyptus grandis and Eucalyptus dunnii," Floresta e Ambiente 25(1). DOI: 10.1590/2179-8087.022815

River, B. H., Vick, C. B., and Gillespie, R. H. (1991). "Wood as an adherend," in: Treatise on Adhesion and Adhesives: Volume 7, J. D. Minford (ed.), Marcel Dekker, Inc., New York, NY, USA, pp. 1-230.

Scheikl, M., and Dunky, M. (1998). "Measurement of dynamic and static contact angles on wood for the determination of its surface tension and the penetration of liquids into the wood surface," Holzforschung 52(1), 89-94. DOI: 10.1515/hfsg.1998.52.1.89

Schneider, C. A., Rasband, W. S., and Eliceiri, K. W. (2012). "NIH Image to ImageJ: 25 years of image analysis," Nature Methods 9(7), 671-675. DOI: 10.1038/nmeth.2089

Sernek, M. (2002). Comparative Analysis of Inactivated Wood Surfaces, Ph.D. Dissertation, Virginia Polytechnic Institute and State University, Blacksburg, VA, USA.

Šernek, M., Kamke, F. A., and Glasser, W. G. (2004). "Comparative analysis of inactivated wood surfaces," Holzforschung 58(1), 22-31. DOI: 10.1515/HF.2004.004

Shi, S. Q., and Gardner, D. J. (2001). "Dynamic adhesive wettability of wood," Wood and Fiber Science 33(1), 58-68.

Siau, J. F. (1984). Transport Processes in Wood, Springer-Verlag, Berlin, Germany. DOI: $10.1007 / 978-3-642-69213-0$

Taghiyari, H. R. (2012). "Correlation between gas and liquid permeability in some nanosilver-impregnated and untreated hardwood," Journal of Tropical Forest Science 24(2), 249-255.

Tarmian, A., Tajrishi, I. Z., Oladi, R., and Efhamisisi, D. (2020). "Treatability of wood for pressure treatment processes: A literature review," European Journal of Wood and Wood Products 78, 635-660. DOI: 10.1007/s00107-020-01541-w

Tesoro, F. O. (1973). Factors Affecting the Flow of Gas and Liquid through Softwoods and Hardwoods, Ph.D. Dissertation, Louisiana State University, Baton Rouge, LA, USA.

Tiemann, H. D. (1910). "The physical structure of wood in relation to its penetrability by preservative fluids," American Railway Engineering and Maintenance-of-way Association Bulletin 120, 359-375. 
Wang, W., Zhu, Y., Cao, J., and Sun, W. (2015). "Correlation between dynamic wetting behavior and chemical components of thermally modified wood," Applied Surface Science 324, 332-338. DOI: 10.1016/j.apsusc.2014.10.139

Weiss, H. F. (1912). "Structure of commercial woods in relation to the injection of preservatives," Proceedings of the Annual Meeting of the American Wood Preservers' Association 8, 159-187.

Wellons, J. D. (1980). "Wettability and gluability of Douglas-fir veneer," Forest Products Journal 30(7), 53-55.

Winandy, J. E., Green, F., and Keefe, D. (2001). “Treatability problems-Relationships between anatomy, chemical composition and treatability," in: Proceedings of $32^{\text {nd }}$ Annual Meeting of the International Research Group on Wood Protection, Nara, Japan.

Windsor Engineering Group. (2020). "Continuous drying kilns (CDK)," (https://www. windsor.co.nz/drying/kilns/continuous-kilns/), Accessed 30 November 2020.

Zhang, Y., and Cai, L. (2008). "Impact of heating speed on permeability of sub-alpine fir," Wood Science and Technology 42, 241-250. DOI: 10.1007/s00226-007-0172-3

Zimmer, K. P., Høibø, O. A., Vestøl, G. I., and Larnøy, E. (2014). "Variation in treatability of Scots pine sapwood: A survey of 25 different northern European locations," Wood Science and Technology 48(5), 1049-1068. DOI: 10.1007/s00226014-0660-1

Zisman, W. A. (1964). "Relation of the equilibrium contact angle to liquid and solid constitution," in: Contact Angle, Wettability, and Adhesion, F. M. Fowkes (ed.), American Chemical Society, Washington, DC, pp. 1-51. DOI: 10.1021/ba-19640043.ch001

Article submitted: September 20, 2020; Peer review completed: October 31, 2020; Revised version received and accepted: November 30, 2020; Published: December 7, 2020.

DOI: $10.15376 /$ biores.16.1.698-720 